\title{
AN ASSESSMENT OF METRICS TO MEASURE SEASONAL VARIATION IN AND GRAZING EFFECTS ON RIPARIAN PLANT COMMUNITIES
}

\author{
Caroline M. Laine ${ }^{1}$, Karin M. Kettenringl,3, and Brett B. Roper ${ }^{2}$
}

\begin{abstract}
AвSTRACT.-Several riparian plant community and streambank metrics were evaluated in 5 streams subject to grazing on public lands in central eastern Idaho. In this study, we evaluated 3 attributes associated with the ground cover on streambanks: percent cover of live vegetation, litter, and bare ground; and we evaluated 4 attributes that describe the vegetation community: plant species richness, wetland index value, percent cover of forbs, and percent cover of graminoids. We were particularly interested in how these attributes differed between grazed and ungrazed sites, how the attributes changed through time, and ultimately how the attributes were able to discriminate the effects of livestock grazing. We found that 2 metrics, percent live vegetation and bare ground, consistently reflected a seasonal effect of grazing. Litter cover also consistently reflected overall seasonal differences, but results often were not significant. Results for species richness suggested this metric may be most applicable when measured at the end of the grazing season. In contrast, we found that the wetland index values and percent cover of graminoids and forbs inconsistently reflected changes in vegetation due to grazing through the growing season. Future work should assess these attributes over several years to determine whether they are better able to discern multiyear trends than current status. By understanding which metrics change over the season and whether they change consistently among riparian areas, land managers can determine which metrics are suitable for short- and long-term monitoring of riparian plant communities. A better understanding of the metrics used to measure cattle grazing may help managers act to improve riparian areas while simultaneously providing ranchers options to graze these sensitive ecosystems.
\end{abstract}

RESUMEN.-Varias comunidades de plantas riparias e indicadores de la ribera, fueron evaluadas en cinco riachuelos propensos a pastoreo localizados en terrenos públicos del centro-este de Idaho. En este estudio, se evaluaron tres atributos asociados a la cubierta del suelo en las riberas: el porcentaje de cobertura vegetal viva, basura y terreno desnudo, y cuatro atributos que describen la comunidad vegetal: la riqueza de especies de plantas, el índice de humedales, el porcentaje de cobertura de herbáceas y el porcentaje de cobertura de gramíneas. Particularmente, nos interesan las diferencias de éstos atributos entre localidades afectadas o no por el pastoreo, cómo los atributos cambian con el tiempo y, por último, cómo los atributos fueron capaces de discriminar los efectos del pastoreo ganadero. Encontramos dos medias, el porcentaje de vegetación viva y suelo desnudo, que reflejan constantemente un efecto estacional del pastoreo. La capa de basura también refleja diferencias constantes dependiendo de cada estación pero, en general, los resultados no fueron significativos. En cuanto a la riqueza de especies, los resultados sugieren que esta medida puede ser más aplicable cuando se mide al final de la temporada de pastoreo. En contraste, encontramos que los valores del índice de humedales y el porcentaje de cobertura de gramíneas y herbáceas reflejan cambios no constantes en la vegetación debido al pastoreo a lo largo de la estación de cultivo. En el futuro es necesario evaluar estos atributos durante varios años para probar si es posible distinguir las tendencias de varios años mejor que el estado actual. Al entender qué medidas varían con cada temporada, y si cambian constantemente entre zonas ribereñas, los administradores de tierras podrían determinar qué indicadores son adecuados para el seguimiento de la ribera a corto y largo plazo. Una mejor comprensión de los índices utilizados para medir el pastoreo de ganado puede mejorar las zonas ribereñas, y al mismo tiempo, proporcionar a los ganadores opciones de pastoreo en estos ecosistemas sensibles.

Changes in riparian vegetation are driven by annual and seasonal variation in temperature, photoperiod, and precipitation, which together control species-specific growth responses and plant communities through the growing season (Boaler 1966, Whittaker 1972, Rathcke and Lacey 1985, Houle and Phillips 1989). Unlike terrestrial environments, riparian communities are further shaped by hydrologic and fluvial processes (Naiman and Décamps
1997) that alter stream channels and water tables, thereby creating new habitats and spatial heterogeneity for plant colonization (Hupp and Osterkamp 1985, Nillson et al. 1994, Pollock et al. 1998, Capon 2005, Lite et al. 2005). The vegetation found in a given riparian area at a specific time therefore reflects the filter of climatic and hydrologic processes. Measures of the conditions of these communities are important to assess riparian and stream processes

\footnotetext{
${ }^{1}$ Ecology Center and Department of Watershed Sciences, Utah State University, Logan, UT 84322.

${ }^{2}$ National Aquatic Monitoring Program Leader, USFS Washington Office-National Service Center, Logan, UT 84322.

${ }^{3}$ Corresponding author. E-mail: karin.kettenring@usu.edu
} 
(Richardson et al. 2007, Aguiar et al. 2011, Hough-Snee et al. 2014).

The rarity of riparian areas in the West, coupled with their high biodiversity, has made them a priority for conservation by public land managers in this region. Although these ecosystems comprise a small portion of the western landscape, they are used disproportionately by wildlife, livestock, and humans. Therefore, special attention should be paid to these systems to ensure that they are effectively managed to avoid long-term degradation (Ffolliott et al. 2004). One of the biggest threats to the condition of western riparian zones is livestock grazing (Fleischner 1994, Belsky et al. 1999).

Stream conditions can be altered by livestock through mechanical disturbance (Hofmann and Ries 1991, Trimble and Mendel 1995), which can alter the composition of riparian plant species (Kauffman et al. 1983, Augustine and McNaughton 1998, Hough-Snee et al. 2013). Breakdown of the streambank by hooves is accelerated through hydraulic action along unvegetated streambanks (Trimble 1994), which creates a sloping bank profile and altered channel morphology. This mechanical disturbance can cause riparian plants to shift from deep - to shallow-rooted species (Reed and Peterson 1961, Trimble and Mendel 1995), resulting in a loss of integrity of stream habitats (Bohn 1986, Clary and Kinney 2002). Loss of above- and belowground vegetation biomass can modify how streambanks alter stream flows, filter sediments, and stabilize soils (Micheli and Kirchner 2002, Burton et al. 2011).

The ability to make good decisions relative to the appropriate level of livestock disturbance requires a monitoring and assessment program sensitive to livestock impacts but relatively unaffected by seasonal variation or short-term hydrologic disturbance. A variety of vegetation response metrics have been suggested for use in assessing riparian plant communities subject to livestock grazing (ColesRitchie et al. 2004, Gibbons and Freudenberger 2006, Lennox et al. 2011, Laine et al. 2013). Many of these response metrics have not been thoroughly tested and should be evaluated for their sensitivity to disturbance, stress (Whitford et al. 1998), seasonal variation, and site differences.

In assessing the ecological health of riparian areas, the evaluation of a suite of metrics is usually preferable to a single measure because multiple metrics can respond differently at different sites and to different stressors (Desoyza et al. 2000, Pyke et al. 2002). Any suite of metrics used as indicators should be sensitive to management activities and be related to ecosystem functions (Herrick and Lal 1995, Whitford et al. 1998). Furthermore, metrics used to evaluate livestock disturbance should have 3 characteristics: metrics should (1) reflect where livestock grazing has altered riparian conditions in a manner that may affect long-term riparian health, (2) be able to discern these changes at the end of the grazing season when most evaluations are usually completed, and (3) be able to be used at the initial state prior to grazing to determine whether the previous year's grazing has degraded the riparian conditions. If a metric consistently provides these 3 outcomes, the information provided by that metric can be used by land managers to effectively manage livestock disturbance. In this study, we evaluate the ability of ground cover measures (percent live vegetation, litter, and bare ground) and several vegetation metrics (plant species richness, wetland index value, percent forb cover, and percent graminoid cover) to describe changes in plant communities throughout a growing season in riparian areas grazed by cattle.

\section{Methods \\ Study Area}

This study was conducted in riparian areas of 5 streams on public lands in the Salmon River and Beaverhead mountain ranges in central eastern Idaho (Fig. 1). The streams had bankfull widths of 3-6 $\mathrm{m}$ and ranged between 1560 and $2300 \mathrm{~m}$ in elevation. The climate is dry, with precipitation occurring as winter snow and spring-summer rain. Rainfall during this study (June-October) was low and averaged $9.5 \mathrm{~cm}$ from June to October (Leadore, Lemhi County, Idaho, USA, weather station). Daily temperatures during the study averaged $14.7^{\circ} \mathrm{C}$ and ranged from $7.3^{\circ} \mathrm{C}$ to $19.2^{\circ} \mathrm{C}$.

Important graminoid species at the sites were Kentucky bluegrass (Poa pratensis L.; nomenclature according to U.S. Department of Agriculture PLANTS Database; USDA NRCS 2011), Nebraska sedge (Carex nebrascensis Dewey), creeping bentgrass (Agrostis stolonifera L.), and smallwing sedge (Carex microptera Mack.). Both Kentucky bluegrass 


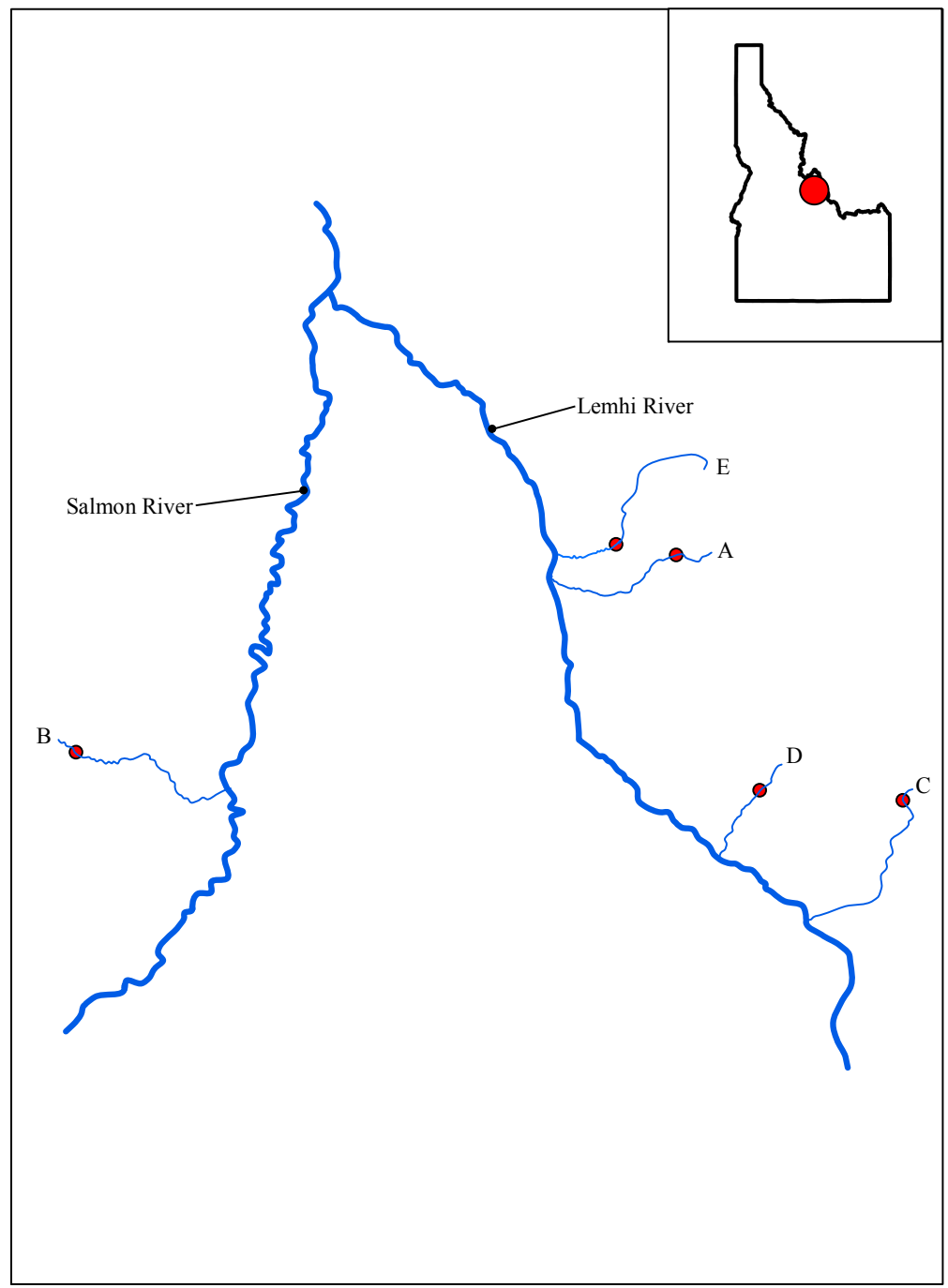

Fig. 1. Streams included in this study: A, Agency; B, Big Hat; C, Canyon; D, Little Eightmile; E, Pattee. Adapted from Laine et al. (2013).

and creeping bentgrass are introduced species that are highly palatable and resistant to cattle grazing. Important shrub species at the sites were big sagebrush (Artemisia tridentata Nutt.), Geyer willow (Salix geyeriana Andersson), and gray alder (Alnus incana (L.) Moench).

\section{Sampling Design}

We chose the 5 streams evaluated in this study because they had grazed and ungrazed (exclosure) sites that were closely juxtaposed and had similar sagebrush and willow riparianvegetation community types. The riparian exclosures at these sites had been in place from 1 to 18 years. Although analysis was based on a case study approach (see Data Analysis section), we looked for consistent patterns across the 5 streams to determine the adequacy of a specific metric for assessing livestock grazing. Specifically, we were interested in metrics that reflected differences in grazing effects across grazed streams and differences in metric responses that are discernable at the beginning and end of the grazing season when evaluations are typically completed by managers.

At every site, we took measurements at 3-m intervals along a 120-m reach, resulting in 40 
TABLE 1. Response metrics assessed in this study and field methods used. All plots sampled at a stream reach for each visit were averaged to arrive at the metric value.

\begin{tabular}{|c|c|}
\hline Metric & Definition \\
\hline Live vegetation cover & $\begin{array}{l}\text { The absolute percentage of a plot that was live vegetation. Plant material was counted } \\
\text { as live vegetation unless it broke off the plant. Putative effects of grazing are to } \\
\text { reduce live vegetation. }\end{array}$ \\
\hline Litter cover & $\begin{array}{l}\text { The absolute percentage of a plot that was litter. Litter included moss and plant material } \\
\text { after it had broken off of the plant. Putative effects of grazing are to reduce litter. }\end{array}$ \\
\hline Bare ground cover & $\begin{array}{l}\text { The absolute percent of a plot that was bare ground. Putative effects of grazing are to } \\
\text { increase bare ground. }\end{array}$ \\
\hline Plant species richness & $\begin{array}{l}\text { The number of plant species per plot that had }>5 \% \text { cover. The putative effects } \\
\text { of grazing go in both directions depending on the species pool present. }\end{array}$ \\
\hline Forb cover & $\begin{array}{l}\text { The relative percent of live vegetation (relative cover) at the plot scale that was forb } \\
\text { species. Putative effects of grazing go in both directions depending on the forb species } \\
\text { pool present. }\end{array}$ \\
\hline Graminoid cover & $\begin{array}{l}\text { The relative percent of live vegetation at the plot scale that was graminoid species. } \\
\text { Graminoids are true grasses in the grass family (Poaceae) and grass-like plants in } \\
\text { the sedge (Cyperaceae) and rush (Juncaceae) families. Graminoids are particularly } \\
\text { important for monitoring because they are often the dominant, perennial, native } \\
\text { vegetation in wetland and riparian habitats and they provide critical habitat for } \\
\text { diverse wildlife. Putative effects of grazing go in both directions depending on } \\
\text { the graminoid species pool present and the species' specific tolerances to grazing. }\end{array}$ \\
\hline Wetland index value & $\begin{array}{l}\text { Each species that had }>5 \% \text { cover within the plot was assigned a wetland index value } \\
\text { based on its likelihood of being found in a wetland area (Reed 1988, USDA NCRS } \\
\text { 2011). These likelihood determinations (=Wetland Indicator Status of USDA NCRS 2011) } \\
\text { were then scaled from } 100 \text { (obligate wetland species) to } 1 \text { (terrestrial species) } \\
\text { (=Wetland Indicator Value of Coles-Ritchie et al. 2007). The Wetland Index Value } \\
\text { used for the present study was calculated for a plot as the sum of the relative cover of } \\
\text { each species multiplied by its Wetland Indicator Value (see Table } 1 \text { and text in } \\
\text { Coles-Ritchie et al. } 2007 \text { for additional details). Previous research has documented that } \\
\text { with grazing exclosures, riparian vegetation shifts from a terrestrial plant-dominated } \\
\text { community to a wetland plant-dominated community due to reduced physical site } \\
\text { disturbances and decreased grazing pressure (Coles-Ritchie et al. 2007). Therefore, a } \\
\text { plot with a high Wetland Index Value would contain a large cover of wetland } \\
\text { species, a sign of a functioning riparian plant community (Coles-Ritchie et al. 2007). }\end{array}$ \\
\hline
\end{tabular}

plots/streambank for 80 total plots/site. The plots were placed along greenline, which is the first line of perennial vegetation upslope from the stream (Winward 2000). Greenline was operationally defined as the closest Daubenmire plot $(50 \mathrm{~cm} \times 20 \mathrm{~cm}$; long axis parallel to greenline) that could be placed adjacent to the stream so that it had a minimum of $25 \%$ perennial vegetation (Leary and Ebertowski 2010, Burton et al. 2011). The lowest location for greenline plot placement was where the streambed met the streambank, and the upper limit was the first flat depositional feature at or above bankfull (Leary and Ebertowski 2010). We established permanent plot locations during the first sample period and returned to the exact same site by driving rebar into the ground in 2 corners of the plot. We used permanent plots for this study because it reduces the sample size necessary to account for the high among-plot-level variability that typically occurs in riparian areas (Elzinga et al. 2001).
At each plot we divided ground cover in the plot into 5 types: percent cover (to the nearest whole number) of live vegetation, litter, bare ground, rock, and logs (see Table 1 for further details on all response variables). To be considered, each type had to cover $>5 \%$ of the plot looking down at the plot from $1 \mathrm{~m}$ (Leary and Ebertowski 2010). In our analysis we evaluated grazing effects on percent cover of live vegetation, litter, and bare ground, but did not use the rock and logs category because grazing would unlikely be able to affect this cover type.

For the portion of the plot that was covered in vegetation, we determined the identity of all species covering $>5 \%$ of the plot. From these vegetation data we calculated a suite of response metrics, including plant species richness (count of unique plant species present), the percent vegetation cover consisting of forbs and graminoids, and a wetland index value (Coles-Ritchie et al. 2004; this was a sliding scale, where if all detected species 
TABLE 2. Grazing dates and number of cattle grazed at streams A-E in 2009.

\begin{tabular}{lccr}
\hline Stream & Grazing dates & Grazing time (weeks of study) & Number of cattle \\
\hline Agency & 22 Jun-27 Jul & $2-7$ & 336 \\
Big Hat & 25 Jul-30 Sep & $7-17$ & 250 \\
Canyon & 5 Jun-12 Jun, 29 Aug-30 Sep & $1,12-17$ & 480 \\
Little Eightmile & 12 Jul-30 Sep & $5-17$ & 218 \\
Pattee & 12 Sep-20 Oct & $14-20$ & 250 \\
\hline
\end{tabular}

were obligatory wetland species [based on the 2012 National Wetland Plant List], the score would be 100, but if they were all upland species, the score would be 1 ; see Table 1 for more details). Reach-scale values were averages of the plot-level results.

To assess overall differences in the response metrics, the same reaches and sites were sampled repeatedly from 10 June to 20 October 2009. We measured the plots at 2 -week intervals during times of peak plant productivity (10 June until the end of August) and at 3week intervals after senescence of plants began in September. Data were collected for 14-19 weeks depending upon the stream and its accessibility (i.e., largely due to the timing of snowmelt and the onset of autumn snowstorms).

\section{Data Analysis}

Because these 5 streams were not randomly selected and the grazing strategies were unique to each pasture (Table 2), we analyzed each stream separately as case studies. Although total livestock numbers in the allotments varied, they were all managed to minimize grazing impacts in riparian use. Riparian management objectives were all set with a goal of maintaining or improving stream conditions. This was done by having riparian standards that limited utilization of riparian vegetation to $<50 \%$ and/or maintained stubble heights $>10 \mathrm{~cm}$.

We evaluated the effect of grazing at each paired site (grazing present and absent) with grazing as a fixed effect and week as a random effect. The goal of this analysis was to determine the adequacy of these metrics to assess the effects of grazing. We began this assessment by evaluating the consistency in the direction of the overall means for each metric between grazed and ungrazed sites across all 5 study streams. If the direction of these differences were consistent, even if the differences were not always significant, these patterns would provide evidence that the metric could be used to evaluate grazing impacts.
When an overall significant difference occurred for a metric at a stream reach, we used a $t$ test to determine whether conditions during the last and first visit were different. We used an $\alpha$ of 0.05 as our critical significance level but listed $P$ values so readers could make their own assessment of significance. Data analyses were conducted using the base and lme packages in $\mathrm{R}$.

\section{RESUlTS}

Two ground-cover metrics-the percent cover of live vegetation and bare ground-gave the most consistent indication of a grazing effect (Table 3; Fig. 2). Not surprisingly, across the 5 streams we assessed, percent cover of live vegetation was greater and bare ground percent cover was lower at ungrazed sites. Significant differences between grazed and ungrazed sites existed for bare ground cover in all streams and for live vegetation in 3 of the 5 streams. Although generally more litter existed in areas subject to grazing, only 2 of these comparisons were significant.

None of the vegetation metrics were consistent indicators of grazing impacts across the 5 sites (Table 3, Figs. 3, 4). Four of the 5 comparisons for greenline wetland index values were significantly different, but 2 scores were higher in grazed sites and 2 were higher in ungrazed sites. A similar pattern was found for plant species richness, but the patterns were contrasting; one site had higher richness at grazed sites, whereas the other site had higher richness at the ungrazed sites. Differences in forb cover were only significant in 2 sites; one stream had more forbs in the grazed riparian zone, whereas the other stream had more forbs in the ungrazed riparian area. Although 4 of the comparisons for graminoids were significant, 2 of the sites with significantly higher graminoid cover were ungrazed and another 2 sites were grazed.

The ground cover metrics also provided the most consistent understanding of the 
TABLE 3. Fixed effects of grazing (present or absent) and $P$ values for the various metrics at each stream.

\begin{tabular}{|c|c|c|c|}
\hline \multirow[b]{2}{*}{ Metric and stream } & \multicolumn{2}{|c|}{ Grazing } & \multirow[b]{2}{*}{$P$} \\
\hline & Absent & Present & \\
\hline \multicolumn{4}{|c|}{ Live vegetation cover $(\%)$} \\
\hline Agency & 78.9 & 61.9 & $<0.01$ \\
\hline Big Hat & 72.5 & 69.5 & 0.37 \\
\hline Canyon & 83.3 & 70.7 & $<0.01$ \\
\hline Little Eightmile & 81.9 & 57.2 & $<0.01$ \\
\hline Pattee & 73.7 & 68.0 & 0.10 \\
\hline \multicolumn{4}{|l|}{ Litter cover $(\%)$} \\
\hline Agency & 13.5 & 17.2 & 0.07 \\
\hline Big Hat & 23.7 & 22.4 & 0.64 \\
\hline Canyon & 14.6 & 21.2 & 0.01 \\
\hline Little Eightmile & 7.0 & 15.1 & $<0.01$ \\
\hline Pattee & 17.0 & 22.0 & 0.12 \\
\hline \multicolumn{4}{|c|}{ Bare bround cover $(\%)$} \\
\hline Agency & 5.2 & 13.7 & 0.02 \\
\hline Big Hat & 2.0 & 5.9 & $<0.01$ \\
\hline Canyon & 0.3 & 5.5 & 0.01 \\
\hline Little Eightmile & 10.6 & 24.0 & $<0.01$ \\
\hline Pattee & 3.4 & 8.1 & $<0.01$ \\
\hline \multicolumn{4}{|c|}{ Plant species richness } \\
\hline Agency & 2.7 & 2.5 & 0.24 \\
\hline Big Hat & 2.6 & 2.8 & 0.09 \\
\hline Canyon & 2.5 & 2.5 & 0.68 \\
\hline Little Eightmile & 3.5 & 2.8 & $<0.01$ \\
\hline Pattee & 2.2 & 2.5 & 0.04 \\
\hline \multicolumn{4}{|l|}{ Wetland index value } \\
\hline Agency & 55.2 & 39.9 & $<0.01$ \\
\hline Big Hat & 56.9 & 62.7 & $<0.01$ \\
\hline Canyon & 83.2 & 73.4 & $<0.01$ \\
\hline Little Eightmile & 40.1 & 38.6 & 0.10 \\
\hline Pattee & 52.9 & 61.9 & $<0.01$ \\
\hline \multicolumn{4}{|l|}{ Forb cover $(\%)$} \\
\hline Agency & 43.4 & 37.6 & 0.12 \\
\hline Big Hat & 36.4 & 33.9 & 0.22 \\
\hline Canyon & 30.4 & 27.2 & 0.11 \\
\hline Little Eightmile & 50.8 & 46.0 & $<0.01$ \\
\hline Pattee & 21.6 & 31.5 & $<0.01$ \\
\hline \multicolumn{4}{|l|}{ Graminoid cover $(\%)$} \\
\hline Agency & 38.0 & 27.0 & $<0.01$ \\
\hline Big Hat & 18.1 & 24.8 & $<0.01$ \\
\hline Canyon & 53.5 & 37.2 & $<0.01$ \\
\hline Little Eightmile & 15.8 & 21.2 & $<0.01$ \\
\hline Pattee & 23.9 & 21.0 & 0.08 \\
\hline
\end{tabular}

trajectory of grazing impacts through a season (Table 4). At the beginning of the season, small differences existed between grazing treatments among streams for the percent of live vegetation, but by the end of the season all of the exclosures had significantly more live vegetation than the grazed reaches. Bare ground percent cover followed a similar pattern; inconsistent and variable differences occurred at the beginning of the season, but consistently more bare ground was found at the grazed stream sites by the end of the year.
Means for wetland index values were statistically different when we evaluated scores at the beginning versus the end of the grazing season. The direction of those differences varied across the 5 streams, suggesting little change in this attribute during the growing season (Fig. 3, Table 4). In contrast, although the signal for plant species richness between grazed and ungrazed reaches differed on a season-long basis, richness was consistently higher in ungrazed reaches by the end of the season (Fig. 3, Table 4). Examinations of differences of both percent cover of forbs and 


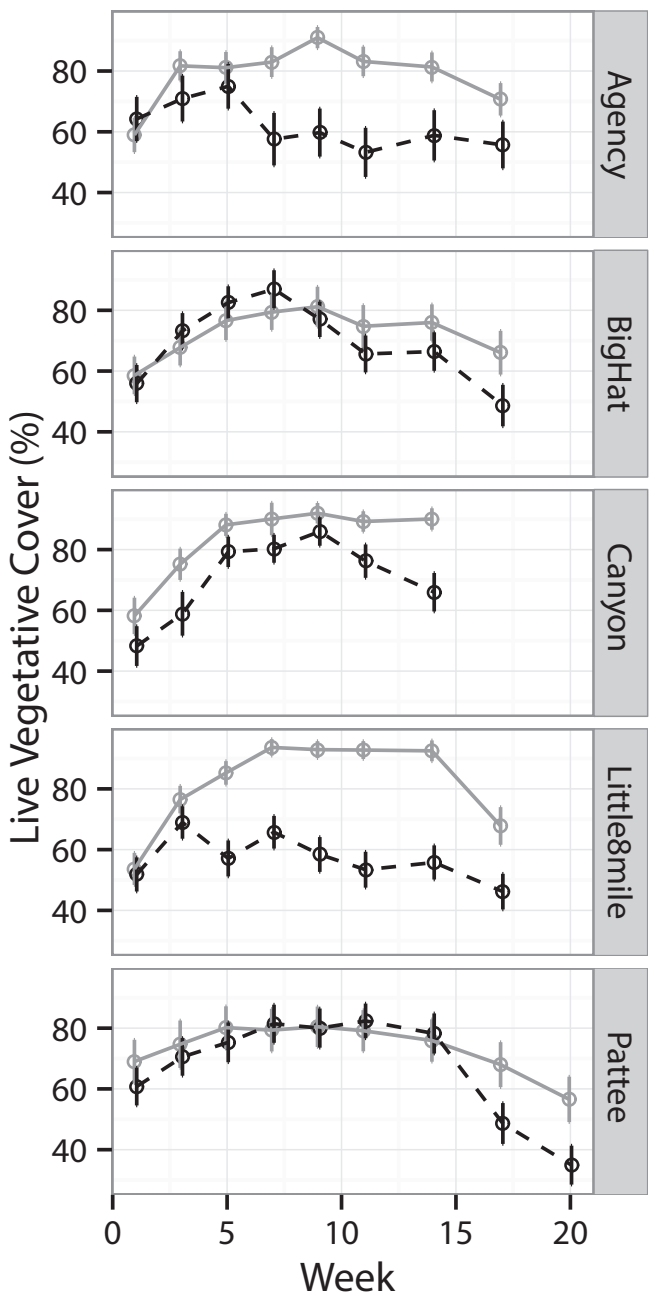

Grazing $\rightarrow$ Absent $\rightarrow$ Present

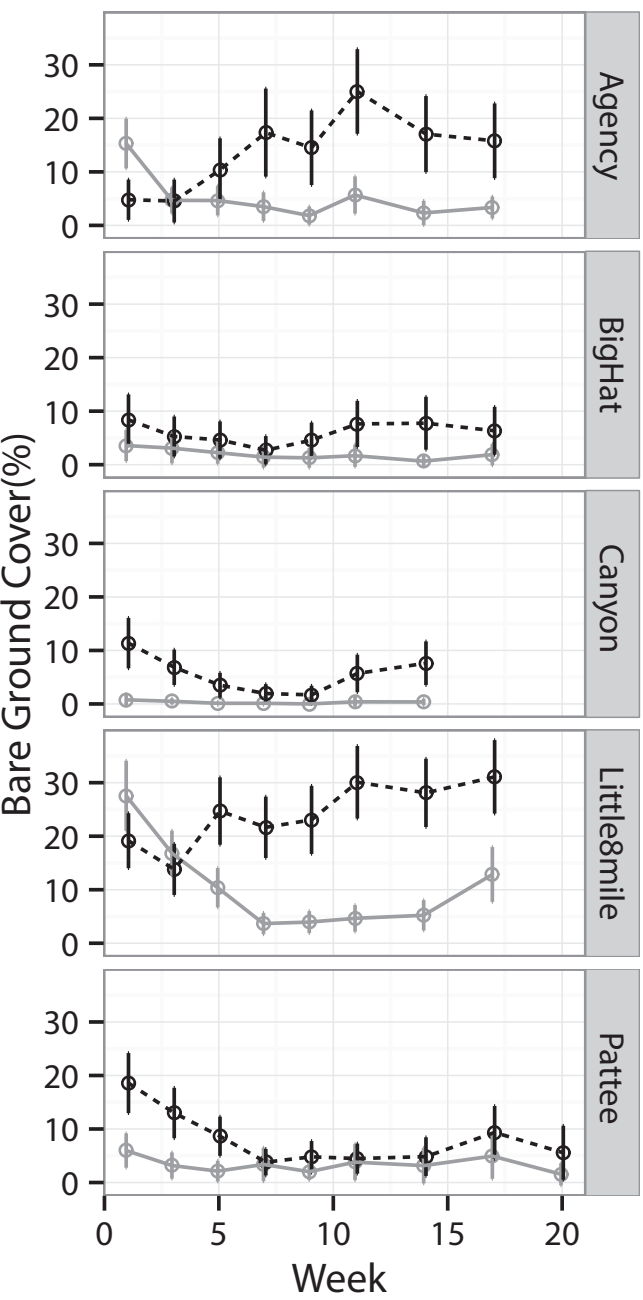

Grazing $-\rightarrow$ Absent $\rightarrow$ Present

Fig. 2. Percent cover of live vegetation and bare ground over the sampling season across the 5 streams we sampled. Error bars represent the $95 \%$ confidence intervals that are based on the measurements taken at that site at that time and are calculated independently for each week.

graminoids showed no consistent signal of grazing either at the beginning or the end of the season (Fig. 4). Furthermore, even though differences occurred in the percent cover of forbs at some points during the growing season, by the end of the season there was no significant difference between sites of different grazing status.

\section{Discussion}

To be useful to managers, metrics used to evaluate the effects of riparian livestock grazing would ideally reflect the influence of grazing within a season as well as across seasons. To meet this objective, measured metrics should change in a predictable manner within a season in response to short-term grazing, but consideration should also be given to metrics that change more slowly and reflect changes in grazing regimes over longer time frames. Thus, an effective livestock grazing monitoring strategy would evaluate several metrics, some intended to track short-term conditions and others to evaluate long-term trends. 


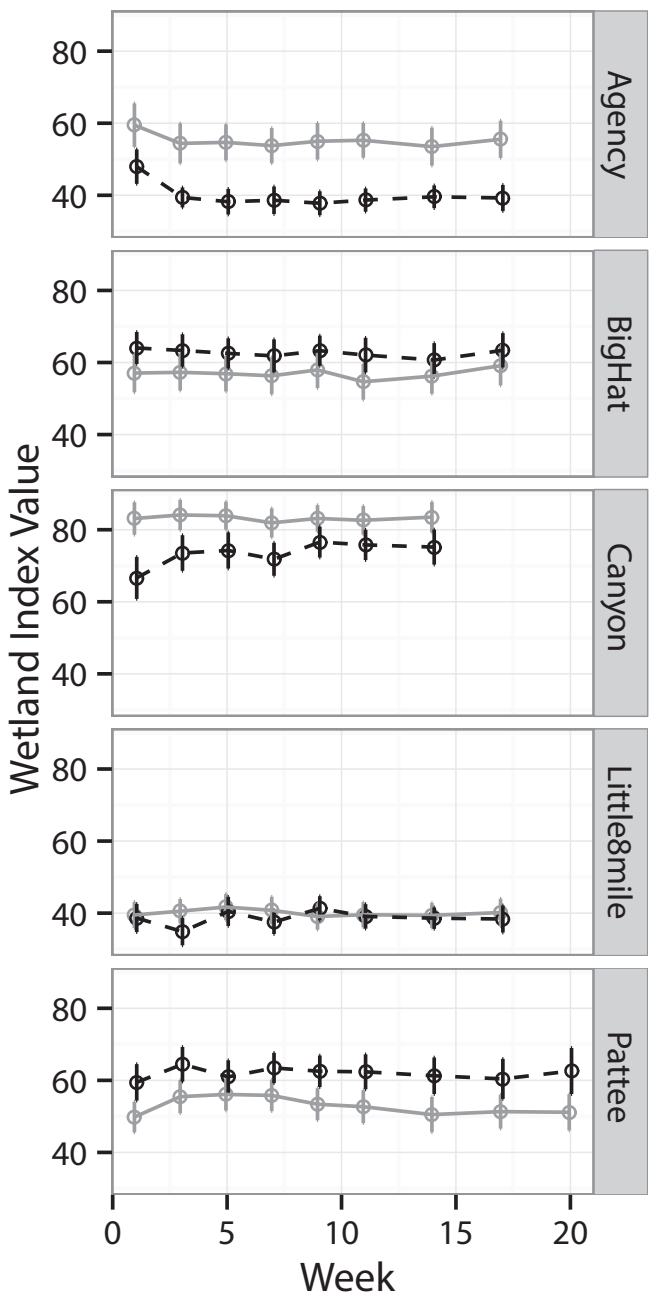

Grazing $\rightarrow$ Absent $\rightarrow$ Present

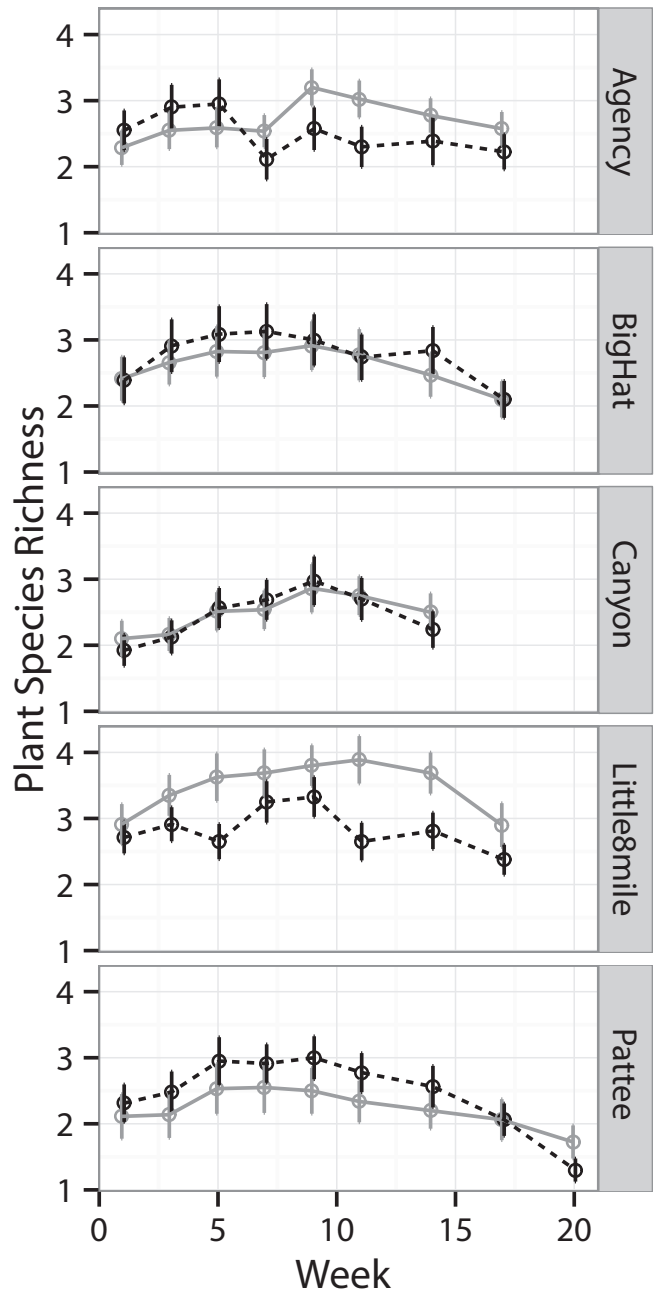

Grazing

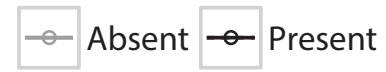

Fig. 3. Wetland index value and plant species richness over the sampling season across the 5 streams we sampled. Error bars represent the $95 \%$ confidence intervals that are based on the measurements taken at that site at that time and are calculated independently for each week.

We demonstrated several metrics that can track short-term changes in conditions due to grazing. These results can be coupled with other research on usefulness of metrics best suited for long-term trend detection (e.g., Bullock et al. 2001, Derner and Hart 2007) for a more comprehensive understanding of grazing impacts on riparian condition.

The metrics we found most consistently related to the presence of livestock within a season were percent cover of live vegetation and bare ground. Throughout the season the percent of vegetation within a plot generally increased in reaches where livestock were absent and decreased when livestock were present. These results were in agreement with other studies that found cattle grazing to be associated with increases in bare ground (Schulz and Leininger 1990, Wahren et al. 1994, Hayes and Holl 2003) and decreased live vegetation cover (Schulz and Leininger 1990, Hayes and Holl 2003). We suggest that these 2 metrics act similarly to other short-term indicators of livestock grazing, such as measures 


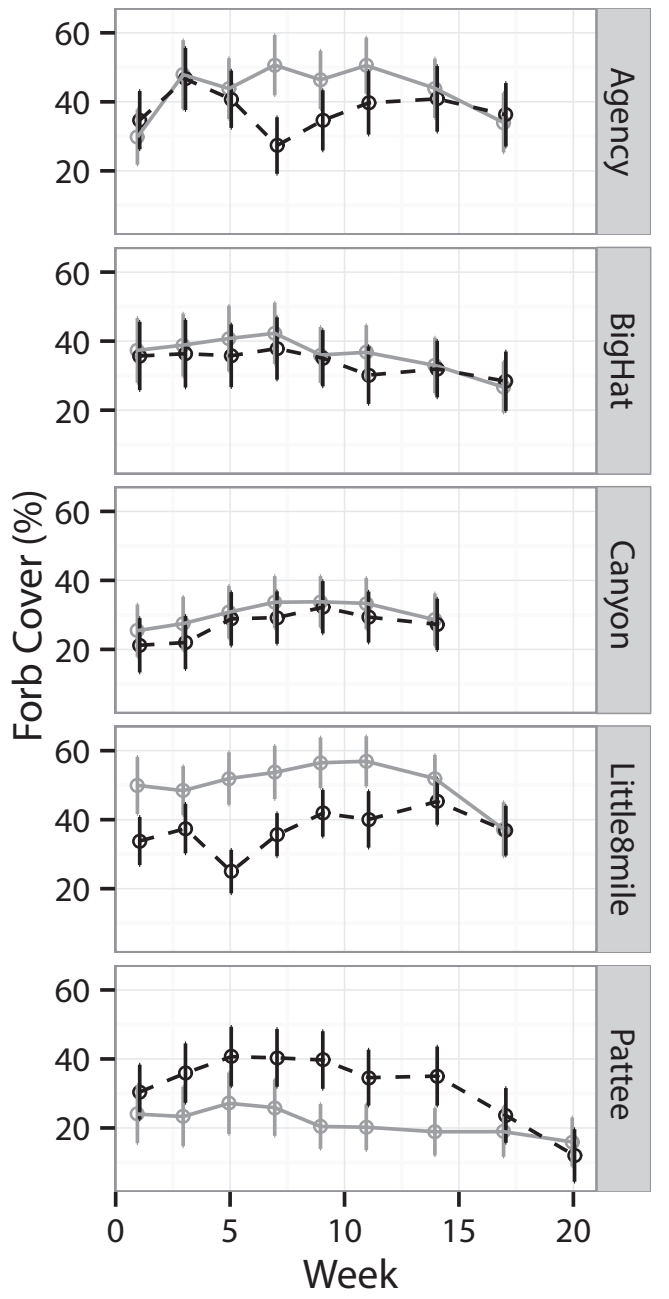

Grazing $-\odot$ Absent $\rightarrow$ Present

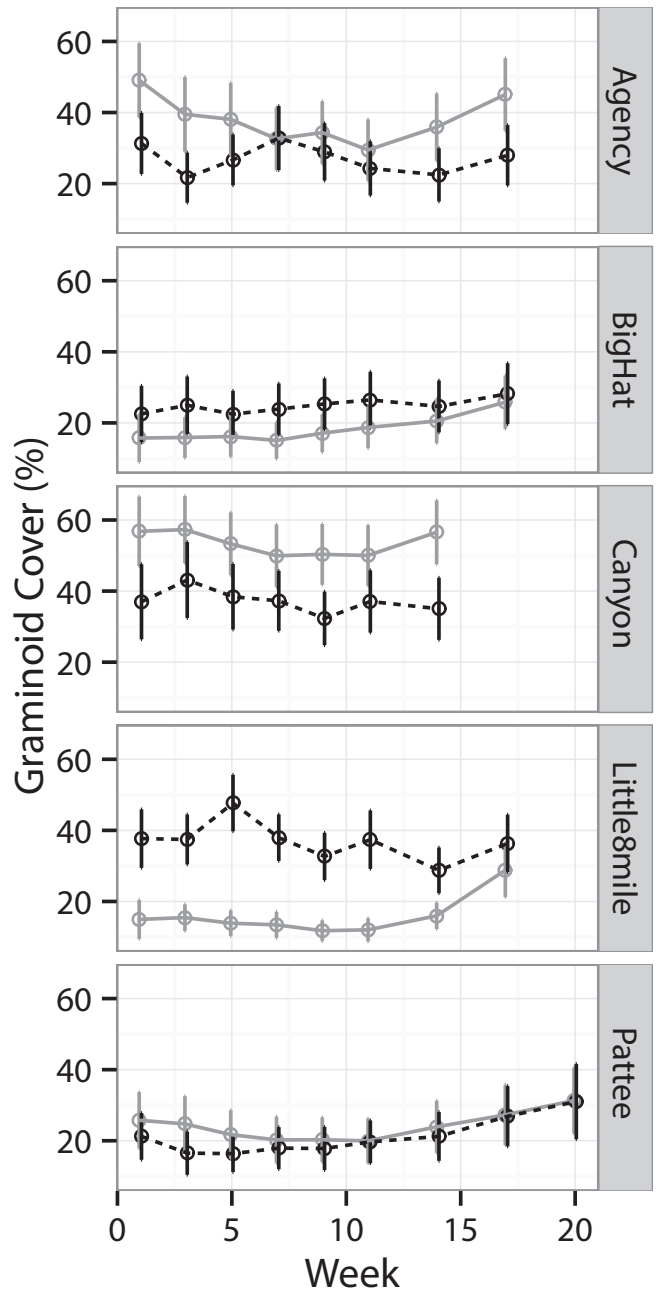

Grazing

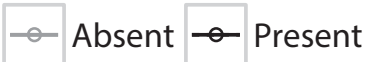

Fig. 4. Percent cover of forbs and graminoids over the sampling season across the 5 streams we sampled. Error bars represent the $95 \%$ confidence intervals that are based on the measurements taken at that site at that time and are calculated independently for each week.

of streambank alteration and near-stream stubble height (Heady 1949, Kauffman et al. 1983, Bengeyfield and Svoboda 1998, USDI BLM 1999, Clary and Leininger 2000, Bengeyfield 2006, Burton et al. 2011), but provide additional important ecological information.

One concern with the measurement of stubble height is that it does not account for areas where grazing has removed vegetation because many protocols avoid these areas (Burton et al. 2011). An increase in bare ground has been found elsewhere in grazing studies
(Schulz and Leininger 1990) and has important implications in that areas without vegetation cover are more likely to be eroded (Clary and Kinney 2002). Although streambank alteration and stubble height might clearly indicate seasonal riparian use by livestock, we suggest that measurement of percent cover of live vegetation and bare ground may provide additional insights into the impacts of livestock disturbance on riparian systems. Another advantage of percent cover of live vegetation and bare ground as metrics is that these attributes 
TABLE 4. Mean differences in response metrics only at the sites and for the metrics that were significantly different (as shown in Table 3) between grazed and ungrazed sites over the entire sampling period.

\begin{tabular}{|c|c|c|c|c|c|c|}
\hline \multirow[b]{2}{*}{ Metric and stream } & \multicolumn{3}{|c|}{ First week (prior to grazing) } & \multicolumn{3}{|c|}{ Last week (following grazing) } \\
\hline & Absent & Present & $P$ & Absent & Present & $P$ \\
\hline \multicolumn{7}{|c|}{ Live vegetation cover $(\%)$} \\
\hline Agency & 59.0 & 64.2 & 0.19 & 70.7 & 55.7 & $<0.01$ \\
\hline Canyon & 58.2 & 48.3 & 0.01 & 90.1 & 66.0 & $<0.01$ \\
\hline Little Eightmile & 53.7 & 51.8 & 0.59 & 67.8 & 46.2 & $<0.01$ \\
\hline Pattee & 69.0 & 60.8 & 0.05 & 56.6 & 24.9 & $<0.01$ \\
\hline \multicolumn{7}{|l|}{ Litter cover $(\%)$} \\
\hline Canyon & 35.3 & 36.1 & 0.84 & 7.5 & 16.4 & $<0.01$ \\
\hline Little Eightmile & 16.3 & 6.4 & 0.04 & 18.5 & 18.9 & 0.89 \\
\hline \multicolumn{7}{|c|}{ Bare ground cover $(\%)$} \\
\hline Agency & 15.3 & 4.8 & $<0.01$ & 3.4 & 12.5 & $<0.01$ \\
\hline Big Hat & 3.6 & 8.4 & 0.05 & 1.8 & 4.5 & $<0.01$ \\
\hline Canyon & 0.8 & 11.4 & 0.13 & 0.4 & 7.6 & 0.09 \\
\hline Little Eightmile & 27.6 & 19.2 & 0.02 & 12.9 & 18.2 & $<0.01$ \\
\hline Pattee & 6.0 & 18.6 & $<0.01$ & 1.6 & 5.6 & 0.09 \\
\hline \multicolumn{7}{|c|}{ Plant species richness } \\
\hline Little Eightmile & 2.9 & 2.7 & 0.24 & 2.9 & 2.4 & $<0.01$ \\
\hline Pattee & 2.1 & 2.3 & 0.30 & 1.7 & 1.3 & $<0.01$ \\
\hline \multicolumn{7}{|l|}{ Wetland index value } \\
\hline Agency & 59.5 & 48.0 & $<0.01$ & 55.5 & 39.3 & $<0.01$ \\
\hline Big Hat & 57.1 & 64.0 & 0.02 & 59.1 & 63.4 & 0.18 \\
\hline Canyon & 83.1 & 66.6 & $<0.01$ & 83.5 & 75.2 & $<0.01$ \\
\hline Pattee & 49.8 & 59.4 & $<0.01$ & 51.2 & 62.6 & $<0.01$ \\
\hline \multicolumn{7}{|l|}{ Forb cover $(\%)$} \\
\hline Little Eightmile & 49.9 & 33.8 & $<0.01$ & 37.2 & 36.8 & 0.93 \\
\hline Pattee & 24.0 & 30.4 & 0.21 & 16.0 & 12.0 & 0.39 \\
\hline \multicolumn{7}{|l|}{ Graminoid cover $(\%)$} \\
\hline Agency & 49.1 & 31.3 & $<0.01$ & 45.1 & 28.0 & $<0.01$ \\
\hline Big Hat & 15.7 & 22.5 & 0.14 & 25.8 & 28.2 & 0.63 \\
\hline Canyon & 56.8 & 47.0 & $<0.01$ & 56.6 & 21.5 & 0.08 \\
\hline Little Eightmile & 14.9 & 37.7 & $<0.01$ & 28.8 & 35.3 & 0.12 \\
\hline
\end{tabular}

may be assessed using remote sensing data such as normalized difference vegetation index (Alhamad et al. 2007). This tool could reduce the costs while greatly increasing the amount of information available to decision makers on the ecological impacts of livestock in riparian areas.

When evaluating riparian areas, the status of metrics at 2 times-right before grazing begins and right after grazing is completedare the most informative to decision makers. To test the value of metrics, paired grazed and ungrazed reaches at a stream would ideally have similar conditions at the beginning of the season. Reasons for differences between paired sites at the beginning of grazing could be due to carry-over effects from the previous year's grazing season or inherent differences in environmental conditions among the paired stream sites. The exact reason for differences will often be difficult to discern because paired grazed and ungrazed sites used in any study will rarely be identical. In our study, metrics with significant differences between grazed and ungrazed sites (Table 3) had a lower number of differences at the beginning of the season for live vegetation cover, litter cover, species richness, and forb cover (Table 4). These findings give some indication that the paired sites were similar and that the previous year's grazing had a limited legacy effect on the sites. Two of these metrics-live vegetation cover and species richness-did end the season with significant differences being in the direction indicative of grazing impacts. In contrast, the amount of bare ground was most likely to be significantly different at the beginning of the season. Given the similarity of grazed and ungrazed sites in the other metrics at the beginning of the growing season, the presence of more bare ground in grazed sites may suggest that some of the effects of the previous year's grazing were carried into the year when our assessment was conducted.

Species richness has been found to increase with cattle grazing (Green and Kauffman 1995, 
Humphrey and Patterson 2000, Pykälä 2003, 2005) as well as decrease or remain unchanged (Brady et al. 1989, Robertson and Rowling 2000, Lucas et al. 2004, Lunt et al. 2007). Our averaging of plot-level data, rather than summing total richness across all plots as is done in most other studies, is beneficial because this approach may better describe the complexity of the stream-reach growing condition than would a cumulative species list. In other words, not only is the choice of metric critical, but also how one chooses to measure and summarize that metric may be important (Heitke et al. 2008, Laine et al. 2013).

We failed to find a consistent seasonal pattern of livestock grazing effect on either forb or graminoid cover across these 5 pastures. This result may reflect our inability to account for native and nonnative species (Hayes and Holl 2003) or it may reflect that the exclosures have been in place for varying lengths of time (Popolizio et al. 1994). Given the variation of environments in which forbs and graminoids can be found, their use as metrics may pose a problem when used across a large number of allotments with different site conditions and livestock grazing histories.

Finally, the wetland index values showed almost no signal of grazing within a season and were inconsistent in the direction of the difference between grazed and ungrazed sites among the 5 streams. This result could be due to variation in conditions at the paired sites and the different length of time in which the exclosures had been in place (Sarr 2002). Coles-Ritchie et al. (2007) found a consistent pattern in grazed and ungrazed stream reaches when the average age of the exclosure was 13 years. Whereas this metric may not be a good within-season indicator of livestock use, it still may be a metric that should be measured through time to show long-term improvement at a site (Winward 2000). Because of the potential differences in paired sites, however, this metric may be best tracked by repeatedly measuring it at the same location through time. With such a study design, an increased wetland index value would show that the reach was moving to a riparian community with more wetland species (Coles-Ritchie et al. 2007).

Overall the metrics that were most responsive to within-season cattle grazing were percent cover of live vegetation, percent cover of bare ground, and species richness. Therefore, these metrics are the most suitable for assessing short-term grazing impacts at an individual site. Given that we collected data over a single grazing season, it is difficult to determine which of these metrics is the best indicator of long-term cattle-grazing pressures. The only way to determine which suite of metrics best evaluates short- and long-term riparian health is to increase monitoring efforts with these and other metrics, which is something the federal land-management agencies have not done well (Veblen et al. 2014).

In this study, we found that seasonal variation is an important consideration for some metrics used to assess grazing impacts on riparian systems but did not affect other metrics. Additionally, we found that some response metrics are better suited for assessing shortterm effects of cattle grazing, whereas others may be better suited for long-term management goals. Through the process of understanding which metrics best describe short- and longterm impacts of cattle grazing, land managers may be able to improve riparian areas while at the same time maintaining ranchers' options to graze these sensitive ecosystems (Holechek et al. 1999).

\section{ACKNOWLEDGMENTS}

We thank the U.S. Forest Service and Bureau of Land Management for funding this research. In addition, many thanks to F.E. Busby and Susan Durham for guidance and manuscript revisions. Thank you to Cheyenne Guillois, Mark Vilardi, and Stacey Frisk for fieldwork assistance and Diane Menuz for database assistance. This research was supported by the Utah Agricultural Experiment Station, Utah State University, and approved as journal paper number 8758 .

\section{Literature Cited}

Aguiar, F.C., M.R. Fernandes, and M.T. Ferreira. 2011. Riparian vegetation metrics as tools for guiding ecological restoration in riverscapes. Knowledge and Management of Aquatic Ecosystems 402: $1-12$.

Alhamad, M.N., J. Stuth, And M. Vannucci. 2007. Biophysical modelling and NDVI time series to project near term forage supply: spectral analysis aided by wavelet denoising and ARIMA modelling. International Journal of Remote Sensing 28:2513-2548.

Augustine, D.J., And S.J. McNaughton. 1998. Ungulate effects on the functional species composition of plant 
communities: herbivore selectivity and plant tolerance. Journal of Wildlife Management 62:1165-1183.

Belsky, A.J., A. Matzke, and S. Uselman. 1999. Survey of livestock influences on stream and riparian ecosystems in the western United States. Journal of Soil and Water Conservation 54:419-433.

Bengeyfield, P. 2006. Managing streams with cows in mind. Rangelands 28:3-6.

Bengeyfield, P., and D. Svoboda. 1998. Determining allowable use levels for livestock movement in riparian areas. Pages 243-257 in D.F. Potts, editor, Proceedings of the Specialty Conference on Rangeland Management and Water Resources, Reno, NV, 27-29 May 1998. American Water Resources Association, Middleburg, VA.

BoAler, S.B. 1966. Ecology of a Miombo site, Lupa North Forest Reserve, Tanzania: II. Plant communities and seasonal variation in the vegetation. Journal of Ecology 54:465-479.

BoHn, C. 1986. Biological importance of streambank stability. Rangelands 8:55-56.

Brady, W., J. Stromberg, E. Aldon, C. Bonham, and S. HENRY. 1989. Response of a semidesert grassland to 16 years of rest from grazing. Journal of Range Management 42:284-288.

Bullock, J.M., J. Franklin, M.J. Stevenson, J. SilverTown, S.J. Coulson, S.J. Gregory, and R. Tofts. 2001. A plant trait analysis of responses to grazing in a long-term experiment. Journal of Applied Ecology 38:253-267.

Burton, T.A., S.J. Smith, And E.R. Cowley. 2011. Riparian area management: multiple indicator monitoring (MIM) of stream channels and streamside vegetation. Technical Reference BLM/OC/ST-10/003+ 1737, USU, U.S. Department of the Interior, Bureau of Land Management Denver, CO.

CAPON, S.J. 2005. Flood variability and spatial variation in plant community composition and structure on a large arid floodplain. Journal of Arid Environments 60:283-302.

Clary, W.P., and J.W. Kinney. 2002. Streambank and vegetation response to simulated cattle grazing. Wetlands 22:139-148.

Clary, W.P., and W.C. LeIninger. 2000. Stubble height as a tool for management of riparian areas. Journal of Range Management 53:562-573.

Coles-Ritchie, M.C., R.C. Henderson, E.K. Archer, C. Kennedy, and J.L. Kershner. 2004. Repeatability of riparian vegetation sampling methods: how useful are these techniques for broad-scale, long-term monitoring? General Technical Report RMRS-GTR138, USDA Forest Service, Fort Collins, CO. http:// www.fs.fed.us/rm/pubs/rmrs_gtr138.pdf

Coles-Ritchie, M.C., D.W. Roberts, J.L. Kershner, AND R.C. HENDERSON. 2007. Use of a wetland index to evaluate changes in riparian vegetation after livestock exclusion. Journal of the American Water Resources Association 43:731-743.

Derner, J.D., and R.H. HarT. 2007. Grazing-induced modifications to peak standing crop in northern mixed-grass prairie. Rangeland Ecology and Management 60:270-276.

Desoyza, A.G., W.G. Whitford, S.J. Turner, J.W. VAnZee, and A.R. Johnson. 2000. Assessing and monitoring the health of western rangeland watersheds. Environmental Monitoring and Assessment 64:153-166.
Elzinga, C.L., D.W. Salzer, J.W. Willoughby, and J.P. GiBBs. 2001. Monitoring plant and animal populations. Blackwell Sciences, Malden, MA.

FFolliott, P.F., L.F. DEBANO, M.B. BAKER, D.G. NEARY, AND K.N. BRooks. 2004. Hydrology and impacts of disturbances on hydrologic function. Pages 51-76 in M.B. Baker Jr, P.F. Ffolliott, L.F. DeBano, and D.G. Neary, editors, Riparian areas of the southwestern United States: hydrology, ecology, and management. Lewis Publishers, A CRC Press Company, Boca Raton, FL.

Fleischner, T.L. 1994. Ecological costs of livestock grazing in western North America. Conservation Biology 8:629-644.

Gibbons, P., and D. Freudenberger. 2006. An overview of methods used to assess vegetation condition at the scale of the site. Ecological Management and Restoration 7:S10-S17.

Green, D.M., and J.B. Kauffman. 1995. Succession and livestock grazing in a northeastern Oregon riparian ecosystem. Journal of Range Management 48:307-313.

Hayes, G.F., AND K.D. HoLL. 2003. Cattle grazing impacts on annual forbs and vegetation composition of mesic grasslands in California. Conservation Biology 17: 1694-1702.

Heady, H.F. 1949. Methods of determining utilization of range forage. Journal of Range Management 2:53-63.

Heitke, J.D., J.C. Henderson, B.B. Roper, and E.K. ARCHER. 2008. Evaluating livestock grazing use with streambank alteration protocols: challenges and solutions. Rangeland Ecology and Management 61:647-655.

Herrick, J.E., AND R. LaL. 1995. Soil physical property changes during dung decomposition in a tropical pasture. Soil Science Society of America Journal 59:908-912

Hofmann, L., and R.E. Ries. 1991. Relationship of soil and plant characteristics to erosion and runoff on pasture and range. Journal of Soil and Water Conservation 46:143-147.

Holechek, J.L., H. Gomez, F. Molinar, and D. Galt. 1999. Grazing studies: what we've learned. Rangelands 21:12-16.

Hough-Snee, N., B.B. Roper, J.M. Wheaton, P. Budy, AND R.L. LOKTEFF. 2013. Riparian vegetation communities change rapidly following passive restoration at a northern Utah stream. Ecological Engineering 58:371-377.

Hough-Snee N., B.B. Roper, J.M. Wheaton, and R.L. LOKTEFF. 2014. Riparian vegetation communities of the American Pacific Northwest are tied to multiscale environmental filters. River Research and Applications, http://dx.doi.org/10.1002/rra.2815

Houle, G., AND D.L. Phillips. 1989. Seasonal variation and annual fluctuation in granite outcrop plant communities. Plant Ecology 80:25-35.

Humphrey, J.W., and G.S. Patterson. 2000. Effects of late summer cattle grazing on the diversity of riparian pasture vegetation in an upland conifer forest. Journal of Applied Ecology 37:986-996.

Hupp, C.R., AND W.R. OSTERKAMP. 1985. Bottom-land vegetation distribution along Passage Creek, Virginia, in relation to landforms. Ecology 66:670-681.

Kauffman, J.B., W.C. Krueger, and M. Vavra. 1983. Effects of late season cattle grazing on riparian plant communities. Journal of Range Management 36: 685-691. 
Laine, C.M., K.M. Kettenring, and B.B. Roper. 2013. An assessment of permanent and nonpermanent plots in riparian vegetation monitoring. Western North American Naturalist 73:337-346.

Leary, R.J., And P.E. Ebertowski. 2010. Effectiveness monitoring for streams and riparian areas: sampling protocol for vegetation parameters. Unpublished Paper, U.S. Department of Agriculture, National Forest Service. http://www.fs.fed.us/biology/resources/ pubs/feu/pibo/pibo_veg_protocol_2010.pdf

Lennox, M.S., D.J. Lewis, R.D. Jackson, J. Harper, S. LaRSON, and K.W. Tate. 2011. Development of vegetation and aquatic habitat in restored riparian sites of California's north coast rangelands. Restoration Ecology 19:225-233.

Lite, S., K. Bagstad, And J. Stromberg. 2005. Riparian plant species richness along lateral and longitudinal gradients of water stress and flood disturbance, San Pedro River, Arizona, USA. Journal of Arid Environments 63:785-813.

Lucas, R.W., T.T. BaKer, M.K. WoOd, C.D. Allison, and D.M. VANLEEUWEN. 2004. Riparian vegetation response to different intensities and seasons of grazing. Journal of Range Management 57:466-474.

Lunt, I.D., A. Jansen, D.L. Binns, and S.A. Kenny. 2007. Long-term effects of exclusion of grazing stock on degraded herbaceous plant communities in a riparian Eucalyptus camaldulensis forest in south-eastern Australia. Austral Ecology 32:937-949.

Micheli, E.R., and J.W. Kirchner. 2002. Effects of wet meadow riparian vegetation on streambank erosion. 2. Measurements of vegetated bank strength and consequences of failure mechanics. Earth Surface Processes and Landforms 27:687-697.

Naiman, R.J., and H. DÉcamps. 1997. The ecology of interfaces: riparian zones. Annual Review of Ecology and Systematics 28:621-658.

Nilsson, C., A. Ekblad, M. Dynesius, S. Backe, M. GardfJell, B. Carlberg, S. Hellovitst, and R. Jansson. 1994. A comparison of species richness and traits of riparian plants between a main river channel and its tributaries. Journal of Ecology 82: 281-295.

Pollock, M.M., R.J. Naiman, ANd T.A. Hanley. 1998. Plant species richness in riparian wetlands-a test of biodiversity theory. Ecology 79:94-105.

Popolizio, C.A., H. Goetz, and P.L. Chapman. 1994. Shortterm response of riparian vegetation to 4 grazing treatments. Journal of Range Management 47:48-53.

PYкÄLÄ, J. 2003. Effects of restoration with cattle grazing on plant species composition and richness of seminatural grasslands. Biodiversity and Conservation 12:2211-2226.

2005. Cattle grazing increases plant species richness of most species trait groups in mesic seminatural grasslands. Plant Ecology 175:217-226.

Pyke, D.A., J.E. Herrick, P. Shaver, and M. Pellant. 2002. Rangeland health attributes and indicators for qualitative assessment. Journal of Range Management 55:584-597.

RathCKe, B., AND E.P. LaCey. 1985. Phenological patterns of terrestrial plants. Annual Review of Ecology and Systematics 16:179-214.

Reed, M.J., and R.A. Peterson. 1961. Vegetation, soil, and cattle responses to grazing on Northern Great Plains Range. U.S. Department of Agriculture, Forest Service, Technical Bulletin No. 1252, Washington, DC. 70 pp.
REeD, P.B. 1988. National list of plant species that occur in wetlands: 1988 national summary. Biological report 88(24). U.S. Department of Interior, Fish and Wildlife Service. http://www.fws.gov/pacific/ecoser vices/habcon/pdf/National\%20List $\% 20$ of $\% 20$ Plant $\%$ 20Species\%201988.pdf

Richardson, D.M., P.M. Holmes, K.J. Esler, S.M. Galatowitsch, J.C. Stromberg, S.P. Kirkman, P. Pyšek, AND R.J. HobBs. 2007. Riparian vegetation: degradation, alien plant invasions, and restoration prospects. Diversity and Distributions 13:126-139.

Robertson, A.I., and R.W. Rowling. 2000. Effects of livestock on riparian zone vegetation in an Australian dryland river. Regulated Rivers: Research and Management 16:527-541.

SARR, D.A. 2002. Riparian livestock exclosure research in the western United States: a critique and some recommendations. Environmental Management 30: $516-526$.

SChulz, T.T., AND W.C. LeININGER. 1990. Differences in riparian vegetation structure between grazed areas and exclosures. Journal of Range Management 43: 295-299.

Trimble, S.W. 1994. Erosional effects of cattle on streambanks in Tennessee, USA. Earth Surface Processes and Landforms 19:451-464.

Trimble, S.W., and A.C. Mendel. 1995. The cow as a geomorphic agent-a critical review. Geomorphology 13:233-253.

[USDA NRCS] U.S. Department of Agriculture, Natural Resources Conservation Service. 2011. The PLANTS database. National Plant Data Team. http://plants.usda.gov

[USDI BLM] U.S. DEPARTMENT OF THE INTERIOR, BUREAU of Land Management. 1999. Utilization studies and residual measurements. Interagency Technical Reference BLM/RS/ST-96/004+1730, Denver, CO. $174 \mathrm{pp}$.

[USDI BLM] U.S. Department of the Interior, Bureau of Land Management and OfFice of the Solicitor. 2001. The Federal Land Policy and Management Act, as amended. Bureau of Land Management Office of Public Affairs, Washington, DC.

Veblen, K.E., D.A. Pyke, C.L. Aldridge, M.L. Casazza, T.J. Assal, and M.A. Farinha. 2014. Monitoring of livestock grazing effects on Bureau of Land Management land. Rangeland Ecology and Management 67:68-77.

Wahren, C., W. Papst, and R. Williams. 1994. Long-term vegetation change in relation to cattle grazing in sub-alpine grassland and heathland on the Bogong High-Plains: an analysis of vegetation records from 1945 to 1994. Australian Journal of Botany 42: 607-639.

Whitford, W.G., A.G. Desoyza, J.W. Vanzee, J.E. HerRICK, AND K.M. HavsTAD. 1998. Vegetation, soil, and animal indicators of rangeland health. Environmental Monitoring and Assessment 51:179-200.

WhitTaker, R.H. 1972. Evolution and measurement of species diversity. Taxon 21:213-251.

WinWARD, A.H. 2000. Monitoring the vegetation resources in riparian areas. U.S. Department of Agriculture Forest Service RMRS-GTR-47, Ogden, UT.

Received 29 November 2013

Accepted 11 December 2014 